\title{
LEGAL PRINCIPLES OF ORGANIC PRODUCTION IN UKRAINE: REALITIES AND PROSPECTS
}

\author{
Dmytro Fedchyshyn ${ }^{1}$, Iryna Ignatenko ${ }^{2}$, Mykhaylo Shulga ${ }^{3}$ \\ *Corresponding author E-mail: marlynkh@gmail.com
}

A R T I C L E I N F O
Review Article
Received: 06 June 2018
Accepted: 09 October 2018
doi:10.5937/ekoPolj1804513F
UDC 340.115:631.174(477)
Keywords:
organic production, agricultural
land, land lease, emphyteusis,
agricultural enterprises,
investments

JEL: P48, P14, D86
A B S T R A C T

The purpose of the article is to consider the prospects of Ukraine concerning attraction of foreign investments into production of organic products. Formal-legal, materialist dialectics and comparative-legal methods are used. The attention is focused on the subjects of legal relations concerning organic production, in particular, on joint ventures with attraction of foreign capital, the stages of certification regarding the production of organic products. The temporary restrictions on the possession of agricultural land in some EU countries and in Ukraine have been analyzed. A comparative analysis of land lease institutions and the right to use another's land for agricultural needs (emphyteusis) has been carried out.

(C) 2018 EA. All rights reserved.

\section{Introduction}

In modern conditions, in many countries of the world, including Ukraine, an active transition to ecologically oriented agriculture of organic production is taking place (Ignatenko, 2017). Organic production is an integral system of food production and management that combines best practices in terms of environmental conservation, biodiversity, conservation of natural resources, the application of high standards of proper maintenance (welfare) of animals, and a production method that meets certain requirements before products made using substances and processes of natural origin.

World volumes of organic food production are continuously increasing, as well as the area under cultivation of crops on organic basis. Also, the number of organic agricultural producers around the world is increasing. According to the estimates of the International Federation of Organic Agricultural Movement the number of producers of organic products has increased 10-fold from 0.2 million in 1999 to 2.3 million in 2016. More

1 Dmytro Fedchyshyn, Ph.D, doctoral student of the department of civil law, Zaporizhzhia National University Zaporizhzhia, Ukraine, Phone: +38 093 6466075, E-mail: marlynkh@gmail.com

2 Iryna Ignatenko, Ph.D, assistant of the department of land and agrarian law, Yaroslav Mudryi National Law University, Kharkiv, Ukraine, Phone: +38 095 3969290, E-mail: nekosargot.ira@mail.ru

3 Dr. Mykhaylo Shulga, professor, head of the department of land and agrarian law, Yaroslav Mudryi National Law University, Kharkiv, Ukraine, E-mail: promin987@gmail.com 
than $75 \%$ of all manufacturers are concentrated in Asia, Africa and Latin America. And the countries with the largest number of them are India (835000), Uganda (210352) and Mexico (210000). In 2016 nearly 57.8 million hectares of land in the world are occupied by organic production. In 1999 there were only 11 million hectares of organic agricultural land. The largest areas are concentrated in Australia - 27.1 million hectares. In the European Union, the area of land occupied by organic production is 13.5 million hectares. The global consumer market for organic products is estimated at about $\$ 89.7$ billion and is characterized by a steady growth trend (compared to 2000 - $\$ 17.9$ billion) (International Federation of Organic Agricultural Movement, 2017).

In the countries of the European Union, whose membership Ukraine wants to receive, the number of farms that grow and sell organic products has significantly increased in recent years. Despite the rather high potential of organic agricultural production on fertile Ukrainian lands, in Ukraine production of such products is still in its early stages of development. At the same time, in recent years there has been a steady trend towards increasing the number of organic farms. Organic production is one of the most dynamic sectors in the Ukrainian agro-industrial complex.

According to statistics, the domestic consumer market of organic products in Ukraine is estimated at 18 million euro, the export potential of the organic sector is estimated at 50 million euro. As of 2017, the number of operators in the organic market has reached 400, compared to 2016, the number of which reached only 284 (Ministry of Agrarian Policy and Food of Ukraine, 2017). This indicates the popularization of organic production in Ukraine. Today there are 16 certification companies-non-residents in the country, which carry out certification of agricultural production according to the rules of organic production, adopted in accordance with the EU Regulation No. 834/2007. The main types of organic products that are produced and consumed in Ukraine are: fruits, vegetables, cereals, meat, bakery products, baby food and dairy products. Exports of this product are made to the countries of the European Union in particular, Germany, Austria, Poland, Italy, France, the Netherlands, Denmark, as well as Switzerland, the USA, Canada.

\section{Materials and methods}

The methodological basis of the study was a complex of philosophical (materialist dialectics) and special legal (formal-legal, comparative-legal) methods of scientific knowledge. The method of materialistic dialectics allowed considering agrarian relations on the creation of organic agricultural products in development and in connection with its normative mediation. The formal legal method made it possible to identify the content of regulatory requirements in the field of organic production. The application of the comparative legal method has made it possible to compare the norms of the national legislation of Ukraine with regard to the production and introduction into circulation of organic products (raw materials) with the legislation of certain foreign countries, the EU and international legal acts. 
The empirical basis for the study was the laws, regulations of Ukraine and other countries on the production of organic products (raw materials), as well as the EU Commission regulations and other international legal acts in this sphere. In, particular, the state policy of Ukraine in the sphere of organic agricultural production is determined by the system of the following strategic regulatory acts, namely: the Constitution of Ukraine, the Law of Ukraine "On the basic principles (Strategy) of state environmental policy of Ukraine for the period till 2020"; the Strategy for the development of the agrarian sector of the economy for the period till 2020; the Strategy for sustainable development "Ukraine 2020"; the Concept of the state target program for the development of the agrarian sector for the period till 2020 etc.

At the same time, the Law of Ukraine "On the production and circulation of organic agricultural products and raw materials", the Resolution of the Cabinet of Ministers of Ukraine "On Approval of the Detailed rules of production of organic products (raw materials) of vegetable origin" and a number of other by-laws are currently considered as the main legislative acts, which define the principles of state policy in the sphere of production and marketing of organic agricultural products.

Consequently, the legal definition of the main directions of the state policy allows agricultural producers to perceive and understand further "steps" in the development of social relations in the sphere of organic production of agricultural products, to plan production and management processes in business, to take an active part in their formation and legal implementation.

\section{Subjects of organic production}

Among the subjects of legal relations on organic production there are individuals and legal entities that have passed the assessment of conformity of production of organic products (raw materials), have received a certificate of conformity and are included in the register of producers of organic products (raw materials). At the same time, the current legislation of Ukraine does not impose any additional requirements on legal entities and individuals who are planning or already engaged in the production of organic products (raw materials). Agricultural enterprises of all types and their associations, as well as economic partnerships, agricultural cooperatives, state-owned enterprises, farms and their associations, private (privately-owned) enterprises, other privately owned enterprises, as well as individualsentrepreneurs and simply individuals can act as parties of legal relationships regarding organic production. But all of them in their activities should take into account the special requirements that are defined by the Law of Ukraine "On the production and circulation of organic agricultural products and raw materials". Foreigners and stateless persons can also obtain the status of subjects, engaged in organic production.

It can exist in various organizational and legal forms - an agricultural society, cooperative, state and communal agricultural enterprises and other business entities, based, for example, on private property. It should be noted that joint ventures with the attraction of foreign capital play an important role in the development of the domestic 
agro-industrial complex. In the conditions of the development of a market economy, these entities may be based on any form of ownership and independently choose the organizational-legal form in accordance with the Commercial Code of Ukraine and the Civil Code of Ukraine, etc.

The concept and status of a joint venture is defined by the Law of Ukraine "On foreign economic activity", which states that joint ventures are enterprises that are based on the joint capital of economic entities of Ukraine and foreign economic entities, joint management and joint distribution of management results and risks (Law of Ukraine, 1991).

At the same time, legislation divides joint ventures depending on the size of the participation of foreign capital in its authorized capital. According to Article 116 of the Commercial Code of Ukraine an enterprise in whose statutory fund at least $10 \%$ is a foreign investment is determined as an enterprise with foreign investments. The law defines the branches of management and the territories in which the total amount of participation of the foreign investor is established, as well as the territories in which the activity of enterprises with foreign investments is limited or forbidden, proceeding from the requirements of ensuring national security (Commercial Code, 2001).

Article 3 of the Law of Ukraine "On the regime of foreign investment" states that one of the forms of foreign investment in Ukraine is the partial participation of foreign investors in enterprises that are created jointly with Ukrainian legal entities and individuals or the acquisition of a share of operating enterprises (Law of Ukraine, 1996).

As noted in the literature, one of the most effective ways of attracting domestic and foreign investors is the creation of joint ventures, although they do not have a quantitative advantage (Ficher, 1999). Joint ventures belong to more complex organizational structures of international cooperation, which carry out their production activities through direct investment (Ülbert, 1992).

One of the best examples of joint ventures in the field of organic production is a UkraineSwiss company "EthnoProduct". 25 percent of the shares of the company are owned by the Swiss company. Since 2008, EthnoProduct's farm and food operations have been certified organic by Organic Standard - a well reputed Ukrainian organic certification body. All products adhere to organic farming and animal husbandry methods, using only natural ingredients during processing to conserve the natural properties of the final food product. The modern farm complex and the newest high-tech milk processing plant make it possible to achieve high quality and product safety indicators. The main activity of the enterprise is the production of organic certified dairy products, the development of the organic products market in Ukraine.

Thus, enterprises with foreign capital are a progressive form of management, an instrument for the formation of market relations in the Ukrainian economy. They, as a form of international cooperation, have a significant impact on integration processes in the global system of management. 
In order to product the organic products (raw materials), individuals and legal entities have the right to carry out certain actions that comprise the content of the certification stages: 1) the confirmation of conformity of production of organic products (passing conformity assessment of organic production, obtaining a certificate of conformity, inclusion in the Register of producers of organic products) and 2) marking.

Certificate of organic land plot - a legal document certifying the legal status of an organic land plot and obliging the owner (user) of the land to grow high-quality organic agricultural products, safe for health and life, environment and other spiritual and material values, their priority implementation in the domestic and international markets. Such certificate is issued to the owner (user) of the land plot, which has undergone the certification procedure in accordance with the procedure established by the Cabinet of Ministers of Ukraine.

In order to ensure the free circulation, import of organic products, the national legal regulation in the field of certification of organic agricultural production must take into account the provisions of the relevant international standards, which can be conditionally divided into:

1. Basic regulatory standards and rules: EU standards: EU Council Regulation 834/2007, EU Commission Regulation 889/2008, EU Commission Regulation 1235/2008; US National Organic Program (NOP); Japanese Agricultural Standards (JAS); Swiss Organic Rules (SOR).

2. International Standards: Basic Standards for Organic Production and Processing of Products (IFOAM IBS) and Codex Alimentarius.

3. Private standards (the most widespread): Naturland, Demeter, ECOLAND (Germany), Bio Suisse (Switzerland), Soil Association (UK), KRAV (Sweden).

In Ukraine, the certification of organic production is carried out according to the following standards: BIOLan - Ukraine (private Ukrainian standards for organic production and labeling of organic products and foodstuffs); European Union standards; Japanese agricultural standards; American agricultural standards; Standards for Bio Suisse.

Among the domestic certification companies are the following: Certification body "Organic Standard", Organic products manufacturers Association "Organic Ukraine", Bio Production Association "BIOLan Ukraine", Federation of organic movement of Ukraine, Association of organic farming and horticulture, Illinetsky Agricultural State College, Organic producers Association "Clean Flora", Information Center "Green Dossier", Retail Academy, etc.

There are 17 international accredited certification bodies in Ukraine (and only one of them is Ukrainian - "Organic Standard"), which are included in the official list of approved certification bodies in the organic sector in accordance with EU Regulation $1235 / 2008$ dated 15.12.2016. An organic producer can apply to any certification body that has international accreditation. 
IFOAM (International Federation of Agricultural Movement) is considered as an international organization that develops standards and monitors compliance with accreditation rules by accredited national organizations. Agricultural products cannot be recognized as "organic" unless they are certified by an IFOAM accredited body and cannot be exported abroad.

Manufacturers of organic products (raw materials) must also be entered to the register provided for in Article 1 of the Law of Ukraine "On the production and circulation of organic agricultural products and raw materials". It should also be noted that the capacity (objects) for the production, processing and marketing of food products and their operators are recorded in the register of facilities (objects) (Law of Ukraine, 2013). Additionally, the above-mentioned entities have to be registered in a central executive body that implements the state policy in the sphere of plant quarantine, in those cases, when such entities produce seed and planting material; carry out storage and processing of grain, etc. (Law of Ukraine, 1993).

The procedure for registration of producers of organic products (raw materials) is established by Article 13 of the said Law and by the Resolution of the Cabinet of Ministers of Ukraine dated August 8, 2016, No. 505 “On Approval of the register of producers of organic products (raw materials)". According to the requirements of the legislation, the responsibility for maintaining the Register of producers of organic products (raw materials) is now assigned to the State Service of Ukraine for Food Safety and Consumer Protection (State Committee for Consumer Safety). Appropriate powers are stipulated by the Regulation on the State Service of Ukraine for Food Safety and Consumer Protection (Resolution of the Cabinet of Ministers of Ukraine, 2015).

Labeling provides identification of agricultural products as organic. In Ukraine, as in the EU countries, labeling of organic products (raw materials) is required. At the beginning of 2017, about 200 farms and about 40 companies - food producers took organic certification in Ukraine. The labeling procedure is regulated by Art. 29 of the Law of Ukraine "On the production and circulation of organic agricultural products and raw Materials", as well as by the order of the Ministry of Agrarian Policy and Food of Ukraine "On Approval of the state logo for organic products (raw materials)".

A mandatory condition for the labeling of organic agricultural products (raw materials) with the state logo in Ukraine is receiving by the manufacturer of such products of the certificate of conformity. The certificate is issued if: a) all ingredients of live or unprocessed agricultural products are organic and produced in accordance with established requirements; b) the processed agricultural products were completely made in accordance with the requirements of the Law of Ukraine "On the production and circulation of organic agricultural products and raw materials" and at least 95 percent of its ingredients are organic, which is in compliance with EU legislation (Law of Ukraine, 2013).

Labeling, which is being derived from an assessment of the conformity of production of organic products, acts as a means of bringing the information about organic products 
(raw materials) to the attention of consumers by the manufacturer (seller). The current legislation of Ukraine provides for the use of state and non-governmental logos when marking organic products. This indicates the existence of an alternative certification system in Ukraine.

\section{Objects of organic production}

An obligatory element of the relations regarding organic production is their object. Objects of legal relations concerning organic production are land plots, land parcels (shares), property, behavior, etc. In the sphere of organic farming among the objects dominant role belongs to land plots.

Today in Ukraine there are about 500 thousand hectares of land where production of agricultural organic products is carried out (Chychkalo-Kondratska, Novytska, 2018). The status of land that is used for this purpose is determined by Article 22 of the Land Code of Ukraine. Thus, according to the aforementioned norm, agricultural lands are recognized as land provided for agricultural production, agricultural research and educational activities, the placement of appropriate production infrastructure, including the infrastructure of wholesale markets for agricultural products, or intended for these purposes (Land Code of Ukraine, 2001). Consequently, the production of agricultural crop products, including organic, can be carried out exclusively on agricultural lands.

The choice of land is an important stage in the process of production of organic products, since the quality of the cultivated product depends on it. The assessment of the suitability of the land (soils) for the production of organic products and raw materials, as well as the establishment of zones for the production of organic products and raw materials are carried out by the State Inspection of Agriculture of Ukraine on the conclusion of the relevant scientific institutions, research institutes, laboratories of quality and safety of products in accordance with the legislation. Such an assessment is made taking into account the ecological and toxicological indices of the agrochemical passport of the land plot and the results of the chemical analysis of test plants that are grown on these soils at the time of the survey. Today, the availability of land agrochemical passport is required. Agrochemical land certification data are used in the process of regulating land relations in: transfer of ownership or provision for use, including lease, of a land plot; change of owner of a land plot or land user; conducting monetary valuation of land; determining the size of the payment for land; carrying out control over the soil fertility condition.

The assessment of the suitability of the lands (soils) is carried out with the aim of obtaining objective information from the interested parties (economic entities producing, transporting, storing and selling organic products, raw materials), establishing their suitability for production organic produce and raw materials, suitable for the production of relevant crops (Fedchyshyn, 2017).

Domestic scientists pay attention to the fact that the land that will be assessed as suitable for organic farming should be recognized as the object of special legal protection in order to ensure the maintenance of the suitability of land plots for future use for the 
cultivation of plant organic products (Kulynych, 2009). Establishing the legal regime for their special protection will serve as a guarantee of the growth of the competitiveness of agricultural products on the world market and is a prerequisite for the prosperity of agriculture in Ukraine.

According to the contents of the Land Code of Ukraine, land plots for the production of organic agricultural products and raw materials can be used on various legal titles: the right of ownership (private, state and communal), the right to permanent use, the right to lease, etc. (Land Code of Ukraine, 2001).

The Constitution of Ukraine declares that the right to ownership of land is guaranteed. Such right is acquired and exercised by citizens, legal entities and the state only in accordance with the law (Part 2 of Article 14 of the Constitution of Ukraine). The Constitution also states that everyone have the right to own, use, or dispose of his property and the results of his intellectual or creative activities; the right for private property should be acquired in compliance with the procedure established by law; no one can be unlawfully deprived of the right for property; the right for private property is inviolable (Constitution of Ukraine, 1996).

Also in accordance with Part 2 of Article 14 of the Constitution of Ukraine the choice of the legal title for the use of agricultural land should be made on the basis of the will of the people, who create farms or other organizational and legal forms of commercial agricultural production (Constitution of Ukraine, 1996).

Today, the bulk of agricultural land in Ukraine is being processed not by the owners of land, but by users of land plots (tenants). The use of the most part of agricultural land by tenants is the main reason for the relatively low level of organic farming development in Ukraine. In its turn, the main reason for the separation of the agricultural producer from the ownership land - is the existence of a moratorium on the alienation of agricultural land (paragraphs 14, 15 of Section X Transitional Provisions of the Land Code of Ukraine). The moratorium is a delay (before January 1, 2019 and adoption of the law on the circulation of agricultural land) in the realization of the right to purchase and sale or other ways of alienation of agricultural land plots and changes in their intended purpose, as well as their inclusion in the authorized capital of enterprises.

In Ukraine, the range of subjects of the right of private property on agricultural land, including those used for organic farming, is legislatively limited. Only citizens of Ukraine and legal entities of Ukraine can act in this role. In accordance with the Article 22 of the Land Code of Ukraine agricultural land cannot be transferred to the ownership of foreigners, stateless persons, foreign legal entities and foreign states. At the same time, according to the Article 81 of the Land Code of Ukraine agricultural land, inherited by foreigners, as well as stateless persons, have to be alienated during the year (Land Code of Ukraine, 2001). The issue of agricultural land received by inheritance by foreign legal entities is solved in a similar way. In turn, for the aforementioned subjects there are no restrictions on the transfer of land plots to the lease. 
It should also be noted that in some foreign countries, temporary restrictions on ownership of agricultural land have also been introduced for foreign citizens and legal entities. Restrictions for foreigners are also used in different volumes: for example, in Brazil there can be no more than $25 \%$ of the agricultural land of the administrativeterritorial unit in the ownership of foreigners; foreigners in the Czech Republic can buy land, if they are citizens of EU member states, and also have more than 3 years of permanent residence in the Czech Republic and registered as farmers. Other countries, such as Estonia, Lithuania, Latvia, Slovakia, Hungary, as well as Bulgaria and Romania, have established a transitional phase (which lasted up to 7 years from accession to the EU). During this period, foreign citizens were not able to buy agricultural land.

In countries which have recently joined the European Union, the application of the aforementioned restrictions on agricultural land to foreigners was due to the fact that in these countries the land market has not completed the system of registration of rights to real estate. The land market was also in the stage of formation and the creation of a land cadastre. In addition, citizens of the abovementioned countries had significantly lower incomes than citizens of other EU countries, the price of land plots was several times smaller than in other EU countries, and therefore they were not competitive in the land market.

The use of lease of agricultural land in the countries of Western Europe has been considerably widespread. In Belgium, for example, about $70 \%$ of the available land is leased, and in France and Germany this figure is $60 \%$. On average, in the EU countries, leased land accounts for $40 \%$ of all agricultural land. In other countries, the figure is significantly lower, for example, 30\% in Canada, 20\% in Japan, 14\% in New Zealand, 12\% in the United States, $5 \%$ in Australia and Argentina.

In a number of countries, there are transparent rules for the use of land with efficiently functioning land markets, in particular, its lease. In this case, the conditions of lease of agricultural land are quite different. Leasing of land is carried out on a contractual basis. There are several main types of such agreements. Agreements of the first type include the state's provisions on the maximum size of the rent and the terms of the contract. Such agreements are usually long-termed and more profitable for lessee, since they support the reduction of the elasticity of the land lease market.

In France, lease agreements mainly belong to the first type of lease of agricultural land and mainly protect interests of tenants: the terms of the lease are long-termed and legally regulated, the terms of the contracts contain provisions that, even after the end of the contract, must ensure the interests of the tenant, the state establishes the upper and lower ranges of rent.

The next type of lease agreement is characterized by the fact that the lease term and price are determined exclusively by market conditions. Lease agreements of the second type are the most widespread in Germany, Sweden, the Czech Republic, Slovakia and Lithuania. Conditions of lease of agricultural land in the specified European countries are determined mainly on the basis of the situation on the land market. 
Both types of lease agreements coexist in Italy and the UK. However, with respect to the part of agreements of the second type, there is a tendency to increase (on the basis of mutual agreement).

Some experts generally believe that land lease agreements are more suitable for the functioning and organization of agricultural land market (Antipova, 2007). As an example, there are two successful countries, namely Israel and the Netherlands, who formed their land relations on the principle of land lease, where the vast majority of agricultural land is state-owned. The main advantages of such an approach are: 1) the excessive concentration of land in the hands of the sole owner and the avoidance of the creation of land latifundia; 2) preventing the grinding of land; 3) the possibility of reserving land for social needs.

The lease is also provided by the legislation of Ukraine. In today's conditions of development of land relations, it plays an important role as one of the dominant forms of realization of property rights and the effective use of land. At present, agricultural enterprises are conducting business activities mainly on leased land, which accounts for about $92 \%$ of their total land use. The basis for the emergence of lease relations is the land lease agreement - the main document defining the relationship between the lessor and the lessee. Ukrainian civil law provides general requirements for the conclusion of lease agreements, and the land legislation reflects the features of this agreement regarding the lease of land plots.

According to Article 93 of the Land Code of Ukraine land plots may be leased to citizens and legal entities of Ukraine, foreigners and stateless persons, foreign legal entities, international associations and organizations, as well as foreign states (Land Code of Ukraine, 2001). The Law of Ukraine "On the lease of land" establishes a list of essential provisions of the land lease agreement, the observance of which is mandatory at the conclusion of the agreement. These include: the object of lease (cadastral number, location and size of land plot); term of the lease agreement; a rent with an indication of its size, indexation, method and terms of calculations, terms, the order of its introduction and review, and responsibility for its non-payment. By the agreement of the parties in the agreement there may be specified other provisions, in particular, the qualitative condition of land, the procedure for fulfilling the obligations of the parties, the procedure for insurance of the object of lease, the procedure for reimbursing the costs for the implementation of measures for the protection and improvement of the object of lease, as well as the circumstances, which may affect the change or termination of the lease agreement, and others (Law of Ukraine, 1998). The Resolution of the Cabinet of Ministers of Ukraine "On approval of the Model land lease agreement" has approved the Model land lease agreement.

The Land Code of Ukraine provides the possibility of concluding land lease agreements for a term of 1 to 50 years (Land Code of Ukraine, 2001). This ensures competition in the market of agricultural land lease, which results in an increase in the size of the rent, the improvement of the forms and conditions of its payment. The terms of agreements 
are different - in the vast majority of them they are concluded for 6-10 years, that is, the prevailing medium-term lease (more than 43.7\%). It seems more expedient to establish a long-term lease of agricultural land and to determine the conditions for early termination of such contracts.

In the legal literature there are discussions on this subject. So, according to M.Shchetina, long-term lease allows the tenant to be guided by the interests of the owner with the corresponding consequences for land use (Shchetina, 2012). On the other hand, by reason of P. Kulynych, the transfer of agricultural land for a long time is unfavorable for peasants, because it is difficult for them to predict the development of land yield due to changes in economic conditions on it and to determine the appropriate amount of rent for their land (Kulynych, 2009).

It is beneficial for any society to use all the resources used to produce goods rationally, that is, in terms of per unit of consumed resources produced the maximum amount of products. Therefore, the state should actively support the tenant in order to reduce the negative process of degradation of agricultural land, reduce the imbalance between the land area and other factors of production. That is why it is expedient to apply longer lease terms allow lessees to invest in long-term improvement of land, the organization of stable production, and to take measures to preserve and protect the soils, which are also used for organic farming.

The economic activity of modern agricultural enterprises based on the lease helps to increase the efficiency of agricultural production. Due to the functioning of the land lease mechanism, active development of entrepreneurial activity in the agrarian sector is taking place. Formed enterprises of the market type, the processes of vertical integration became more active, which in aggregate contributes to the provision of food security of the state and to the growth of the export potential of organic products.

The emphyteusis, which is a right to use another's land for agricultural needs, became widespread recently. This right is long-term, alienable and inherited. It was introduced into the land legislation of Ukraine in 2007 and since then became a tangible competitor to the lease law institute. It is very relevant and has differences from the lease.

In accordance with Article 102-1 of the Land Code of Ukraine, the right to use another's land plot for agricultural needs (emphyteusis) arises on the basis of an agreement between the land plot owner and a person who has expressed a will to use this land for such needs, in accordance with the Civil Code of Ukraine (Land Code of Ukraine, 2001).

The significance of emphyteusis is also aggravated by the fact that, with almost complete blockage of the secondary market of agricultural land, it is advisable to appeal to an alternative institute that can ensure the interests of the user to obtain more reliable and stable rights than with the conclusion of the lease.

Unlike the land lease agreement, the essential provisions of the agreement on the emphyteusis are not defined by law. In accordance with Part 1 of Article 638 of the Civil Code of Ukraine an agreement can be concluded, if the parties have duly reached a consensus on all its 
essential provisions. Essential provisions of the agreement are the subject of the agreement, provisions that are established essential by the law or necessary for the agreements of a specific type as well as all those provisions, in respect thereof a consensus is to be reached upon application of at least one of the parties (Civil Code of Ukraine, 2003).

According to Article 632 of the Civil Code of Ukraine the price in the agreement should be determined upon the agreement between the parties. In cases established by the law the prices (tariffs, rates etc) established or regulated by the authorized governmental bodies or local self-governments should be applied. The rent for land plots of state and communal property is a regulated price, and therefore the legislative change of the maximum amount of this fee is the basis for revision of the rent amount established by the provisions of the contract (Civil Code of Ukraine, 2003). That is why the privatelaw nature of the regulation of emphyteusis is advantageously different from the overly regulated obligations of lease of land.

Part 2 of Article 21 of the Law of Ukraine "On the lease of land" makes special demands regarding the terms of rent payment for land plots of state and communal property. In contrast, the agreement on the emphyteusis provides full freedom in determining the size, form and timing of payment for this agreement (Law of Ukraine, 1998). Consequently, the payment for such use of land is paid to the owner of the land in the size, form, in order and in the terms specified in the agreement on the right to use another's land for agricultural needs.

The advantage of emphyteusis over the lease agreement is the unlimited duration of its validity, as well as the one-time receipt of the entire amount of money by the owner of the land, while under the lease agreement the owner will receive funds in installments. The advantage of emphyteusis is also that such a right, unlike the lease, may be indefinite, whereas the latter is limited to 50 years. But it should also be borne in mind that an indefinite agreement of emphyteusis can only be if the land is privately owned. The term of use of the land plot of state or communal property for agricultural needs also cannot exceed 50 years (Article 4, Article 102-1 of the Land Code of Ukraine and paragraph 1 of Article 408 of the Civil Code of Ukraine).

Taking into account the benefits of emphyteusis on its indefinite duration, those who want to purchase agricultural land are often offered to conclude an agreement of emphyteusis. After the conclusion of the agreement, the citizen will be "almost the owner" of the land, since he receives the latter not only for the indefinite possession and use, but can still dispose of the acquired right. In particular, according to the Article 102-1 of the Land Code of Ukraine and Article 407 of the Civil Code of Ukraine the right to use another's land for agricultural needs (emphyteusis) may be alienated and transferred in order of inheritance, except for the right to use the land plot of state or communal property which cannot be alienated to other persons (except for cases of transfer of ownership to buildings and structures), deposited in the authorized capital, transferred to a pledge. In addition, emphyteusis can be a convenient means to ignore the prohibition of the acquisition of agricultural land by foreigners and stateless persons. 
Legislative consolidation of legal mechanisms for the further development of relations of agricultural land use laid the foundations for sustainable development of relations in the sphere of organic production in Ukraine.

\section{Discussions}

One of the most rational and ecological methods of agricultural production is the organic farming, which ensures proper protection of the environment, rational use of land and other natural resources, ensuring the production of quality and nutritious food. Organic production plays a double social role, when, on the one hand, it involves the functioning of a special market that meets the needs of consumers in organic products, and, on the other hand, provides the public with products that promote the protection of the environment and the welfare of animals, as well as the development of the countryside.

The total area of certified organic agricultural land is growing rapidly, which today accounts for $1 \%$ of Ukraine's total agricultural land. According to the territories, which are occupied by organic production, Ukraine ranks 22nd in the world (Trofimtseva, 2017). At the same time, according to the FAO (Food and Agriculture Organization), the agroecological potential of yield in Ukraine is 6.2 tons per hectare and is the highest in the world, but in fact its only 2.5 tons per hectare (Nahorna, 2011). Consequently, Ukraine has significant potential and prospects for forming the agro-ecological image of the country of organic farming.

Creation of joint ventures in the sphere of organic production is now extremely relevant and positive. Joint ventures invest heavily in new technologies for product quality management, stimulate the process of production of competitive products, facilitating its access to international markets.

Modern activation of the development of domestic organic production is the result of the fact that Ukraine has favorable conditions for organic agriculture due to the large area of agricultural land, among which a significant share belongs to fertile black soil, convenient geographical location, proximity to potential international buyers and ever-increasing demand for organic products on the domestic and foreign markets.

\section{Conclusions}

The need for solving environmental problems and the issue of providing people with good-quality food products is closely linked to the need for a transition from traditional to organic farming. At the same time, it is important for the agricultural producers of Ukraine to develop ecological production in order to increase competitiveness in the markets of Ukraine and the world. Organic farming in Ukraine as a large agricultural country has a unique potential, which involves the development of agriculture and attracting investment. World agricultural development confirms that biotechnology will become more and more important in the future. 
Taking into account the joint desire of state authorities, businesses to bring Ukraine to the world's leading positions in producers of organic products, the ever-increasing demand for organic products in the domestic and world markets, there is every reason to hope that Ukraine will remain a source of high-quality organic products and a reliable partner in the organic business for the international market, on the gradual rebirth of soil fertility and the improvement of the environment. For this purpose, the implementation of the legislative framework of Ukraine to the EU legislation is carried out. Today the legislation provides opportunities for foreign capital for organic production in Ukraine through the creation of joint ventures. In addition, Ukraine has a system of certification of producers and products of organic origin that meets all European standards. At the same time, the law provides for certain restrictions for foreigners, which are aimed at ensuring the national interests of the state. This is, first of all, a moratorium on the purchase of agricultural land by foreigners. However, the availability of such types of land use as lease and emphyteusis, enables foreign citizens and companies to successfully engage in organic production on the territory of Ukraine.

\section{Conflict of interests}

The authors declare no conflict of interest.

\section{Literature:}

1. Antipova, L. (2007). Involvement of foreign experience in organization of landlease relations. Economy AIC, 1, 147-153. [in Ukrainian: Антіпова, Л. (2007) Залучення зарубіжного досвіду організації земельно-орендних відносин].

2. Cabinet of Ministers of Ukraine (2015). Resolution "On Approval of the Regulation on the State Service of Ukraine for Food Safety and Consumer Protection ”. № 667. [in Ukrainian: Кабінет Міністрів України (2015) Постанова Про затвердження Положення про Державну службу України 3 питань безпечності харчових продуктів та захисту споживачів]. Retrieved from http://zakon3.rada.gov.ua/ laws/show/667-2015-п. (April 30, 2018)

3. Chychkalo-Kondratska, I., Novytska, I. (2018) World experience of promotion of organic products. Effective economy, 2. [in Ukrainian: Чичкало-Кондрацька, I., Новицька, I. (2018) Світовий досвід просування органічної продукції]. Retrieved from http://www.economy.nayka.com.ua/pdf/2 2018/10.pdf

4. Fedchyshyn, D. (2017). Some features of exercising of rights toland for organic farming. Collection of materials of the international scientific and practical conference: Legal principles of organic farming, Department of Land and Agrarian Law, 29-30.09.2017, Ukraine, Kharkiv, Domino, 224-227. [in Ukrainian: Федчишин, Д. (2017). Деякі особливості здійснення прав на землі для органічного землеробства].

5. Ficher, P. (1999). Foreign direct investment and governments. New York.

6. Ignatenko, I. (2017). Legal aspects of building on lands for organic farming in private agricultural activity. Collection of materials of the international scientific 
and practical conference: Legal principles of organic farming, Department of Land and Agrarian Law, 29-30.09.2017, Ukraine, Kharkiv, Domino, 75-80. [in Ukrainian: Ігнатенко, I. (2017). Правові аспекти забудови земель для ведення органічного землеробства в особистому селянському господарстві].

7. International Federation of Organic Agricultural Movement (2017) Consolidated annual report of IFOAM - Organics International. Retrieved from https:/www. ifoam.bio/en/our-library/annual-reports (April 30, 2018)

8. Kulynych, P. (2009). Production of organic and environmentally friendly agricultural products: land-legal aspects. State and Law, vol. 43, 414-420. [in Ukrainian: Кулинич, П. (2009). Виробництво органічної та екологічно чистої сільськогосподарської продукції: земельно-правові аспекти].

9. Ministry of Agrarian Policy and Food of Ukraine (2017). Organic production in Ukraine: realities and perspectives. Retrieved from https:/www.slideshare.net/ TarasKutoviy/ss-72695482 (April 30, 2018)

10. Nahorna, O. (2011). Will Ukraine be an "organic" breadbasket of Europe? Land Investment Bulletin of Ukraine, 9, 10-12. [in Ukrainian: Нагорна, О. (2011). Чи стане Україна “органічною” житницею Свропи?].

11. Shchetina, M. (2012) Theoretical aspects of leasing land relations in Ukraine. Collection of scientific works of Vinnytsia National Agrarian University. 3 (69), 249-253. [in Ukrainian: Щетина М. А. Теоретичні аспекти орендних земельних відносин в Україні].

12. Trofimtseva, O. (2017) Organic sector in Ukraine. [in Ukrainian: Трофімцева, O. (2017). Органічний сектор в Україні]. Retrieved from http://www.ukraine. fibl.org/fileadmin/images-ukraine/Biofach_2017/Organic in Ukraine abstract Deputy Minister Olga Trofimtseva UA.pdf.

13. Ülbert, J. (1992). Beruházások gazdaságtana. JPTE Kiadó. Budapest.

14. Verkhovna Rada of Ukraine (2001) Commercial Code of Ukraine. № 436-IV. [in Ukrainian: Верховна Рада України (2001) Господарський кодекс України]. Retrieved from http://zakon5.rada.gov.ua/laws/show/436-15 (April 30, 2018)

15. Verkhovna Rada of Ukraine (2001). Land Code of Ukraine. № 2768-III. [in Ukrainian: Верховна Рада України (2001) Земельний кодекс України]. Retrieved from http://zakon3.rada.gov.ua/laws/show/2768-14 (April 30, 2018)

16. Verkhovna Rada of Ukraine (1996). Constitution of Ukraine. № 254к/96-ВР. [in Ukrainian: Верховна Рада України (1996) Конституція України]. Retrieved from http://zakon0.rada.gov.ua/laws/show/254к/96-вp (April 30, 2018)

17. Verkhovna Rada of Ukraine (2013). Law of Ukraine "On the production and circulation of organic agricultural products and raw materials”. № 425-VII. [in Ukrainian: Верховна Рада України (2013) Закон України “Про виробництво та обіг органічної сільськогосподарської продукції та сировини”]. Retrieved from http://zakon0.rada.gov.ua/laws/show/425-18 (April 30, 2018) 
18. Verkhovna Rada of Ukraine (1991). Law of Ukraine "On the foreign economic activity”. № 959-XII. in Ukrainian: Верховна Рада України (1991) Закон України "Про зовнішньоекономічну діяльність"]. Retrieved from http://zakon3.rada.gov. ua/laws/show/959-12 [(April 30, 2018)

19. Verkhovna Rada of Ukraine (1993). Law of Ukraine "On the quarantine of plants". № 3348-XII. [in Ukrainian: Верховна Рада України (1993) Закон України “Про карантин рослин"]. Retrieved from http://zakon2.rada.gov.ua/laws/show/3348-12 (April 30, 2018)

20. Verkhovna Rada of Ukraine (1998). Law of Ukraine "On the lease of land”. № 161XIV. [in Ukrainian: Верховна Рада України (1998) Закон України "Про оренду землі"]. Retrieved from http://zakon5.rada.gov.ua/laws/show/161-14 (April 30, 2018)

21. Verkhovna Rada of Ukraine (1996). Law of Ukraine "On the regime of foreign investment”. № 93/96-BР. [in Ukrainian: Верховна Рада України (1996) Закон України “Про режим іноземного інвестування"]. Retrieved from http://zakon3. rada.gov.ua/laws/show/93/96-вp (April 30, 2018)

22. Verkhovna Rada of Ukraine (2003). Civil Code of Ukraine. № 435-IV. [in Ukrainian: Верховна Рада України (2003) Цивільний кодекс України]. Retrieved from http://zakon5.rada.gov.ua/laws/show/435-15 (April 30, 2018) 